\title{
The Shapes Jane Eyre Takes: Ephemeral Responses to the Book and Its Themes
}

IN TWO WORDS, "JANE EYRE" - the name of a book and the name of a character-book and character merge, indistinguishably. When casually dropped, the name might bring to mind the tidy rectangles of mass-market paperbacks or clothbound hardbacks, or the flesh of any number of famous actresses who have played the part of Charlotte Brontë's most famous heroine. Two dimensions become three-words are transmitted via material sources, and those material sources are interpreted through the veil of human desires. And so Brontë's text, like a word whispered from person to person in a game of telephone, carries with it the residue of all those who associate themselves with it. The novel is printed; prefaces are written; adaptations are created for stage and screen. Illustrations are added. Texts are translated, abridged, annotated, and edited. Other novels crop up in reply. However, we must not view these later manifestations as being simply a series of garbled, dubious distortions of a formerly intact and correct, original message. Instead, we might understand these transmissions, in their various forms, as a series of replies through history that allow us to see what fascinated us enough about the story to repeat it, what cultural predispositions and preoccupations underpinned its retellings, and, ultimately, how and why the story continues to survive.

Readers do not simply ingest Jane Eyre; they make the book and the character their own through responses that reflect impressions left by the text as it was materially transmitted to them. These responses are not exclusively literary. There are also cigarette cards, stamps, and postcards; author cards and trivia games; tea towels, thimbles, and refrigerator magnets; commemorative plates and coins; porcelain figures and paper dolls; miniature books designed for doll houses; glass patterns, bracelets, and blouses. These, too, are "Jane Eyre" - whether one finds them in the gift shop of the Brontë Parsonage in Haworth or posted in the auctions of eBay. Such objects form a penumbra that irresistibly follows the novel through all of its printed manifestations. And yet, in our historical and critical studies of the novel, we do not concern ourselves with them. We prefer to chase, in our intellectual fashion, more sanctioned, written forms. Why is this so? 
The question has bothered me ever since the autumn of 2004, when I first began curating Rare Book School's Jane Eyre collection. While I was familiar with the contents of the collection before I worked directly with it, strangely enough, the ephemera/realia question never bothered me when I was an impartial spectator and someone else-Rare Book School's former Curator of Collections, John Buchtel-its keeper. I never thought to ask "Why the tea towel? Why the thimble?" I was simply drawn to these objects, which, as bizarre as they were, surprised and delighted me. But when Buchtel left Rare Book School in 2004 to become Curator of Rare Books at Johns Hopkins and I took on the responsibility of building and maintaining the collection, the problem quickly became obvious. Jane Eyre dolls popped up on eBay. Could I justify acquiring one? I found wedding invitations quoting text from Jane Eyre. How did these relate to the Jane Eyre collection and its mission? If our goal was to show how a novel becomes famous, I wondered, should we not try to include as many different manifestations of it as possible?

Buying the materials, I learned, was the simple part. Interpreting them was harder. It is easy enough to turn a collection of ephemera and realia into a circus; as with any freak show, one can simply point a finger at the oddities and, with little explanation, shock and entertain an audience. It is more difficult to explain why these materials exist in the first place and how they matter with respect to Brontë's novel.

Academics tend to privilege academic responses to literature over popular ones. And they do not always easily adapt themselves to understanding popular culture with the same critical focus with which they treat canonical texts. In her study Loving with a Vengeance: Mass-produced Fantasies for Women, Tania Modleski writes: "women's criticism of popular feminine narratives has generally adopted one of three attitudes: dismissiveness; hostility...; or, more frequently, a flippant kind of mockery." Though Modleski wrote this in 1982 with reference to Harlequin romances and the like, the same holds true today for responses toward the kinds of ephemera and realia included in the Jane Eyre collection. Indeed, one needs look no further than the Peabody Library's "Eyre Apparent" exhibition in 2007, which I co-curated with John Buchtel, for evidence of lighthearted mockery. But to demonstrate just how "hostile" some treatments can be: in 2005, an article by Tanya Gold appeared in The Guardian that attacked Elizabeth Gaskell, Charlotte Brontë's first biographer, as presenting an unrecognizably "sanatised" [sic] version of the author-one that systematically concealed the true nature of Brontë's passionate personality. In her conclusion, Gold shows how pervasive an influence has been exerted by Gaskell and, by way of evidence, reports Gaskell's impressions of the Brontë Parsonage Museum in Haworth, England, with venomous disdain:

1. Tania Modleski, Loving with a Vengeance: Mass-produced Fantasies for Women (1982; New York: Routledge, 1990), 14 . 
There is every Brontë-branded item the mother of the cult [Elizabeth Gaskell] could wish, except, perhaps, enormous golden Bs. I choose a gold fridge magnet, a tea-towel that says "Brontë genius-love, life and literature" and a toy sheep stamped with the word "Brontë." There is a Jane Eyre mouse mat that says, "I am no bird and no net ensnares me; I am a free human being with an independent will." This souvenir disgusts me, but no doubt Mrs Gaskell would love it. In Jane Eyre, Charlotte Brontë wrote "independent human being." She did not write "independent mouse mat." I can find no remnant of the breathing, brilliant novelist in Haworth; it is merely the site of a death cult that weirdly resents its god ... I yearn to rip the road signs down and torch the parsonage. This shrine needs desecrating, and I want to watch it burn. I want to see the fridge magnets melt, the tea towels explode ... Somewhere in the ashes there might remain a copy of Jane Eyre. That is all of Charlotte Brontë that need loiter here. ${ }^{2}$

One wonders exactly what Tanya Gold did with her toy sheep when she returned from the parsonage. But clearly, she suggests that those who innocently consume such material goods are out of touch with the novel and deluded as to the real identity of its author. I ask why such material objects exist in the first place: Gold's version would have it that they are part of a Gaskell-originated conspiracy designed to turn Charlotte Brontë into an acceptable literary saint, devoid of sexual longing and dark emotion. If this were so, then Gold should credit Gaskell as being more than a "mediocre writer" and, instead, acknowledge her biography as the work of a political and literary genius capable of duping millions of unwitting readers. But this is also not the case. The truth is that these objects, tea towels and magnets, have little to do with Gaskell and more to do with ourselves: we want them, that is why they are here. They are our replies to the novel, our small tribute to its power. For many, the words on the mousepad serve as inspiration — not denigration. This fact must be acknowledged and recorded, however obvious it seems. The rest of this article will explore how we might interpret such ephemera and realia with clarity and intelligence; and in doing so, I will try to suspend the three nonvirtues of dismissiveness, hostility, and mockery, which ultimately cannot be helpful in understanding these objects.

When analyzing material objects with respect to a novel like Jane Eyre, we quickly fumble for vocabulary. For example, I have been using the terms "ephemera" and "realia" to loosely differentiate between short-lived two-dimensional, printed objects and three-dimensional collectibles or souvenirs. However, the terms are up for grabs, and more sophisticated definitions of either might introduce ideas of intention: was the object's maker intending it to be systematically collected? Was the maker conscious or unconscious of the object's relationship to the text

2. Tanya Gold, "Reader, I Shagged Him," The Guardian (25 March 2005). Available online from http:/ / books.guardian.co.uk/departments/classics/story/0,,1445404,00.html. 
that served as its inspiration? While, superficially, stamps might seem more like ephemera, and glassware more like realia, the categories can begin to blur and overlap. For example, the Jane Eyre stamps issued by the British Royal Mail in 2005, which featured the artwork of Paula Rego, were marketed explicitly toward stamp collectors, while the Seneca glass pattern entitled "Jane Eyre" that modeled itself loosely on a nineteenth-century pattern seems more a happenstance-an otherwise anonymous item created for everyday use and one unlikely to be collected because of its association with the novel.

Similarly, when talking about the objects in the Jane Eyre collection, it can be difficult to distinguish between "kitsch" and "camp." If kitsch is bad art that is both naive and sincere, campy objects are (if we follow Susan Sontag's definition ${ }^{3}$ ), for the most part, affected, over-the-top, self-aware, and stylish. Is the British Library "Reader, I married him” egg cup kitsch or camp? Such distinctions can make it very hard to interpret objects, and they present a special challenge for the curator or scholar who attempts to classify them according to such means. For the present, I have chosen to talk about the ephemera and realia in the Jane Eyre collection according to theme, which has the added advantage of allowing me to compare directly groups of objects to ideas expressed elsewhere in the collection, and in the novel itself.

A theme that constantly recurs through the collection is that of the "old book." For example, Rare Book School owns a small set of leather-covered drawers, circa 2004, that were made to resemble three leather-bound volumes stacked one atop another (see figure 1). The titles of the "books" are hand painted in gold and the "spines" most likely intended to imitate hand-tooled bindings (though considering the

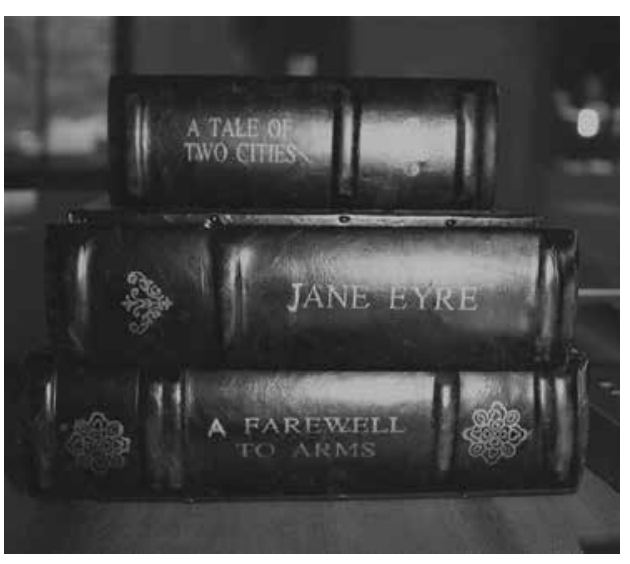

Figure 1. Hand-painted, leather-covered drawers made to resemble books, ca. 2004. Jane Eyre Collection, Rare Book School. design, it is extremely unlikely that they were made after any physical copies). The titles are Jane Eyre, $A$ Tale of Two Cities, and A Farewell to Arms. Clearly, these books were grouped together because they are all famous classics. The fact that Hemingway is twentieth-century and American, while the other two are nineteenth-century and British, emphasizes that the common link rests on household name appeal alone. These are the kinds of books that most children in

3. Susan Sontag, "Notes on 'Camp,"” collected in Against Interpretation and Other Essays (New York: Farrar, Straus \& Giroux, 1966). 
the United States are —or at least used to be-required to read in high school. It is probably safe to say that this piece was not aimed at an audience familiar with literature or the history of the book; rather, the leather-bound drawers were created for ornament, their design satisfying a vague nostalgia for old books and classic literature. Along the same lines, a piece of late twentieth-century wallpaper, designed to resemble over-full bookshelves, conveys a vague sentimental longing for old classics (see figure 2). As with the decorative drawers, the designs of the bindings as they are graphically represented are nonspecific and historically uninformed, and they probably were created purely according to the artist's personal sense of what an "old book" is supposed to look like. Jane Eyre and Wuthering Heights are depicted as

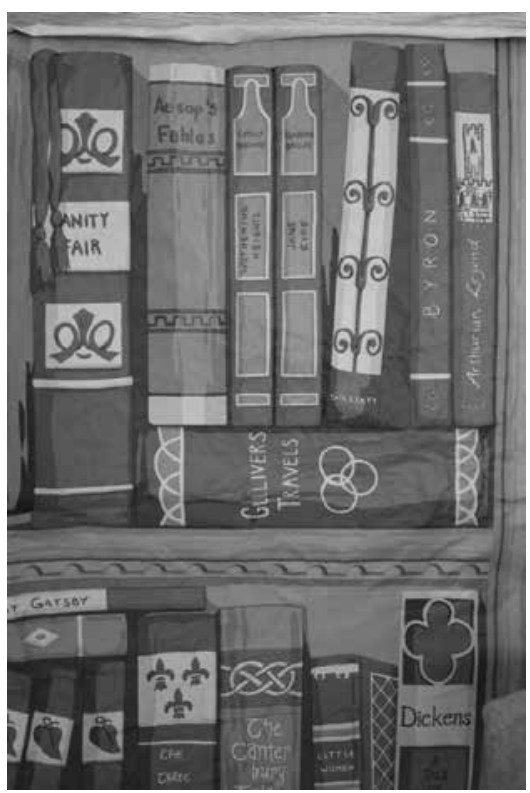

Figure 2. Detail of late 20th c. wallpaper depicting famous classics. Gift of Colonel David K. and Mrs. Jan E. Cannon to Rare Book School's Jane Eyre Collection, 2006. standing, with other volumes, on top of a copy of Gulliver's Travels laid flat; the unlikely arrangement betrays an artist who is unfamiliar with the habits of bookworms. The idea of the book, in both instances, is far more important than the experiences that real, physical books afford.

We tend to think of books in one way, but then, in our daily lives, treat them otherwise; this is an important fact to remember when understanding the larger role that Jane Eyre, the novel, plays in society. For, practically, no matter how attached our society might be to the idea of old books, reading itself is on the decline. In the United States, the 2004 report that followed the 2002 Survey of Public Participation in the Arts conducted by the National Endowment for the Arts revealed that "for the first time in modern history, less than half the adult population now reads literature." ${ }^{4}$ Compare this with another more recent finding. In March of 2007, the United Kingdom's Literacy Trust found, through a survey of 4,000 readers, that "a third of those questioned read 'challenging literature' in order to seem well-read, even though they couldn't follow what the book was about." According to the

4. National Endowment for the Arts, Reading at Risk: A Survey of Literary Reading in America. (Washington, D.C.: National Endowment for the Arts, 2004), vii. Available online from www.arts.gov/pub/ ReadingAtRisk.pdf.

5. National Literacy Trust, "Reading to Impress-And Bluffing Your Way Through" (March 2007) Available online from www.literacytrust.org.uk/Database/Mori.html\#bluffing. 
same survey, "almost half" of those questioned said that reading classic literature "makes you look more intelligent." Among the top ten books people most bluffed about reading were Wuthering Heights (number three) and Jane Eyre (number eight). The message is clear: Jane Eyre is not only an important book to know-it is an important book to seem to know.

It probably comes as no surprise that I have not yet found wallpaper imitating rows of mass market paperbacks; neither have I found drawers designed to imitate late nineteenth-century paperbacks. Fancy leather bindings and gold seem tied to general notions of old classics. However, among dollhouse miniatures, Jane Eyre lives a surprisingly rich and varied life. The book exists as a miniature "deluxe" binding, a miniature facsimile nineteenth-century binding, a miniature mass-market paperback, and a miniature comic. Clearly, Jane Eyre, in the world of miniaturists, is many things to many people.

Jane Eyre is one of more than five hundred different miniature books designed and published by Barbara Raheb, proprietor of the Pennyweight Press. ${ }^{6}$ Rare Book School's copy, which was donated to the school by dollhouse aficionado Patricia Pistner, is number 184 in a limited edition of 300 copies. As one might expect, it imitates physical attributes typical of fine press productions: the book is bound in scarlet goatskin that has been stamped in gold; it contains marbled endpapers and black and white lithograph illustrations. The book has also been signed, in very small script, by its designer. The text inside is an abridged adaptation of the novel, not a word-for-word excerpt. Although the book is striving for a fine-press look, its details remain somewhat crude, and, on the whole, the little volume is more evocative of mass-produced works published by the Franklin Library or Easton Press. Perhaps this is because Franklin Library and Easton Press productions are also in the business of imitating high style. However, it is worth noting that the Pennyweight Press edition currently fetches more than three times what an Easton Press volume would cost; luxury, in the world of miniatures, does not come cheap.

But if dollhouse collections are small-scale expressions of the real world as it is perceived (and idealized) by dollhouse collectors, Jane Eyre is not just another pretty book. Rare Book School recently acquired a miniature facsimile of a late 1870s clothbound hardback of Jane Eyre originally published in Worthington's Franklin Edition series of fiction. ${ }^{7}$ When comparing the covers of the small, paperback miniature to an actual book from the series, aside from a difference in color, the designs look identi-

6. Charlotte Brontë, Jane Eyre (Agoura Hills, Calif.: Pennyweight Press, 1990). Statistic taken from "400 Years of Miniature Books," an exhibition at the Lilly Library, June 18 to September 15, 2001 Available online from www.indiana.edu/ liblilly/exhibitions/miniatureschecklist.shtml.

7. Facsimile created circa 2005, purchased from www.treefeathers.com. The book is blank inside. 
cal. For a dollhouse collector interested in capturing the look of a late 1870s American bookshelf, one could hardly do better. Similarly, a miniature paperback, published circa 2004 by Cottage Industries, a small firm specializing in dollhouse miniatures, features covers pirated from the contemporary Signet Classic edition introduced by Erica Jong. ${ }^{8}$ The covers, although poor in quality, retain most of the detail of the original, even down to the barcode on the lower cover-the only difference is that Cottage Industries has cropped off the Signet Classics title from the upper portion of its cover. When studying an actual Signet edition next to its miniature cousin, one can even see the difference in proportion where the cut has been made.

While I cannot yet trace the exact source for the miniature comic book entitled "Girl," which contains a comic strip of Jane Eyre, the object is a miniature representative of a surprisingly large number of popular comic adaptations of Brontë's novel. ${ }^{9}$ Among these, the Classics Illustrated Jane Eyre is perhaps most instantly recognizable, but there are also Pocket Classics, Thriller Classics, and numerous foreign language comic translations that heavily adapt and illustrate the book from novel to picture strip. As one might suspect, these productions are geared toward children, and the title of our mini comic, "Girl," underscores the fact.

In addition to these books, I have also found Jane Eyre sold in a bundle with other miniatures. This, too, provides its own kind of evidence. Consider a set purchased from eBay within the last year: among the novels, one finds Jane Eyre, Pride and Prejudice, Emma, Portrait of a Lady, and Princess Daisy(?)! The presence of Judith Krantz in connection with Charlotte Brontë, Jane Austen, and Henry James illustrates, in a very succinct way, how classics are read and consumed alongside contemporary popular romances.

Taken as a whole, these miniature books reflect a popular fascination with Jane Eyre that extends beyond the generic status of "old classic"; it is apparent from this sample that the book exists, ideally, as a luxury binding, nineteenth-century binding, bestseller, children's story, and romance. I use the word "ideal" to stress the fact that ideas are what drive miniature productions over details. The fact that the book, even on such a small scale, exists in so many different shapes and forms attests to its ability to adapt itself continually to wide-ranging needs within the popular market.

Moving away from the theme of books imitating books, ephemera and realia can also reveal, in new light, popular preoccupations that tend to fall outside the

8. Charlotte Brontë, Jane Eyre (New York: Signet-New American Library-Penguin Putnam Inc., 1997).

9. "Girl," created circa 2005; no publisher's information. Rare Book School owns comic adaptations of Jane Eyre published by Classics Illustrated (Gilberton Company), Acclaim Classics Illustrated (Acclaim Books), Pocket Classics (Academic Industries), Hooked on Phonics (Gateway Educational ProductsPendulum Press), Livewire Graphics (Hodder \& Stoughton), and Thriller Comics (Amalgamated Press). 
academic radar. For example, many people recognize Jane Eyre not as an orphan or governess, but simply as a bride. Take for example the Jane Eyre doll, dressed in full wedding costume, which was designed in 1990 by Robin Woods (see figure 3). Or a

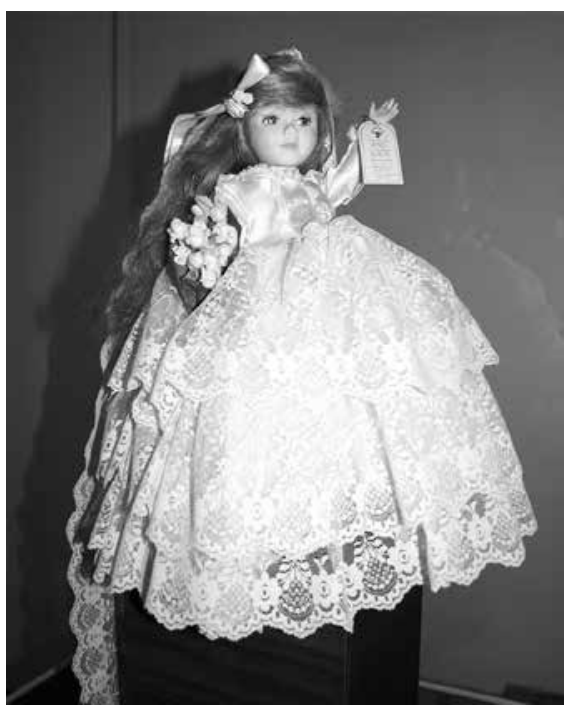

Figure 3. "Jane Eyre” doll created by Robin Woods in 1990. Jane Eyre Collection, Rare Book School. wedding journal, which contains the quotation "Reader, I married him." Or wedding invitations, found on eBay, that include a line from the novel that recounts Jane's feelings for Edward Rochester after ten years of marriage: "I know what it is to live entirely for and with what I love best on earth." Or a 2005 article from New York magazine, which uses the name "Jane Eyre" in connection with "ethereally prude" fashion models adorned in bridal costume. ${ }^{10}$ How can one book inspire a cheerful, blonde doll named Jane Eyre and, at the same time, a morbid-looking bride? Is Jane Eyre an innocent, wide-eyed child, or is she the figure of the death-stalked prude that Tanya Gold lambastes? In a very simple sense, she is both. In the novel, death and childhood are bedfellows-literally-as in the scene at Lowood in which Jane Eyre is found with her arms twined around the dead body of her best friend, Helen Burns. One can say the same for notions of death and sex, which also shadow one another in the book. Take, for example, Bertha Mason, whose madness and suicide are inextricably linked with unchecked passion. Or consider Disciplining Jane, a retelling of the novel that explores the sado-masochistic underbelly of gothic romance ${ }^{11}$ (see figure 4). If the doll is too beautiful, too unlike the novel to be believed, perhaps it is because the maker is inadvertently imposing a happy ending on these provocative and troubling themes. Whatever the case may be, both the book and character continue to inspire responses that address women's fears and hopes with respect to ideas of sexuality and marriage.

And the thimbles? The tea towels? The fridge magnets? The commemorative plates? The pins and stickers, cigarette cards, and author cards? The bracelets and earrings, bearded iris, and drinking glass? Should we torch them, as Tanya Gold proposes, or should we let them die a slow death, fading into an unrecorded,

10. Harriet Mays Powell and Amy Larocca, "5 X 10 Fall 2005 Forecast," New York (28 March 2005). Available online from http://nymag.com/nymetro/shopping/fashion/fall2005/europe/11546/index1. html.

11. Jane Eyre [pseud], Disciplining Jane (New York: Blue Moon Books, 2001). 
obscure past? I hope the reader agrees that neither solution is satisfying and that these materials deserve to be saved. One could spend time on every object and come to useful conclusions with respect to the book and its role in society. At the very least, tracking these objects helps gauge, at any given moment, a book's popularity. But, as I hope I have also shown, these materials, with a little attention, also reveal sentiments, attachments, and desires that are otherwise difficult to

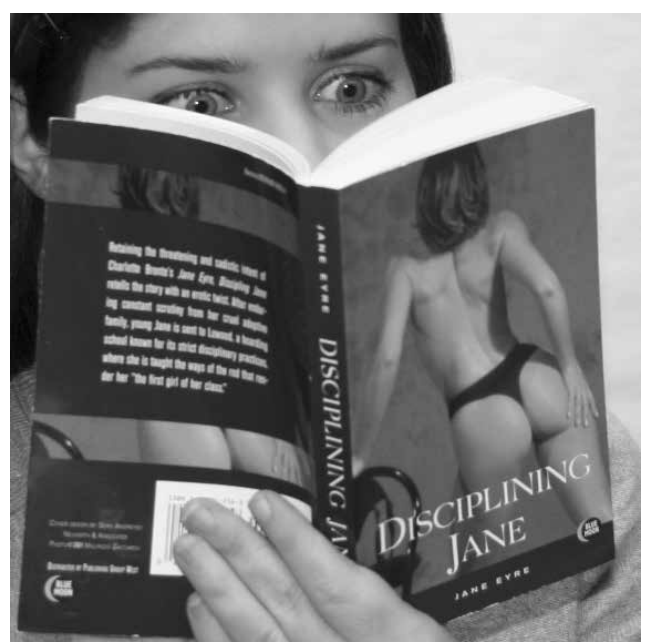

Figure 4. A reader contemplating Disciplining Jane. Jane Eyre Collection, Rare Book School. put into words. Obnoxious and tender, perverse and funny, ephemera and realia expose our unpolished, unedited selves. They are the history that escapes the history books. Finally, collecting and treating these objects with respect can only better illuminate our understanding of what popular books like Jane Eyre mean to us.

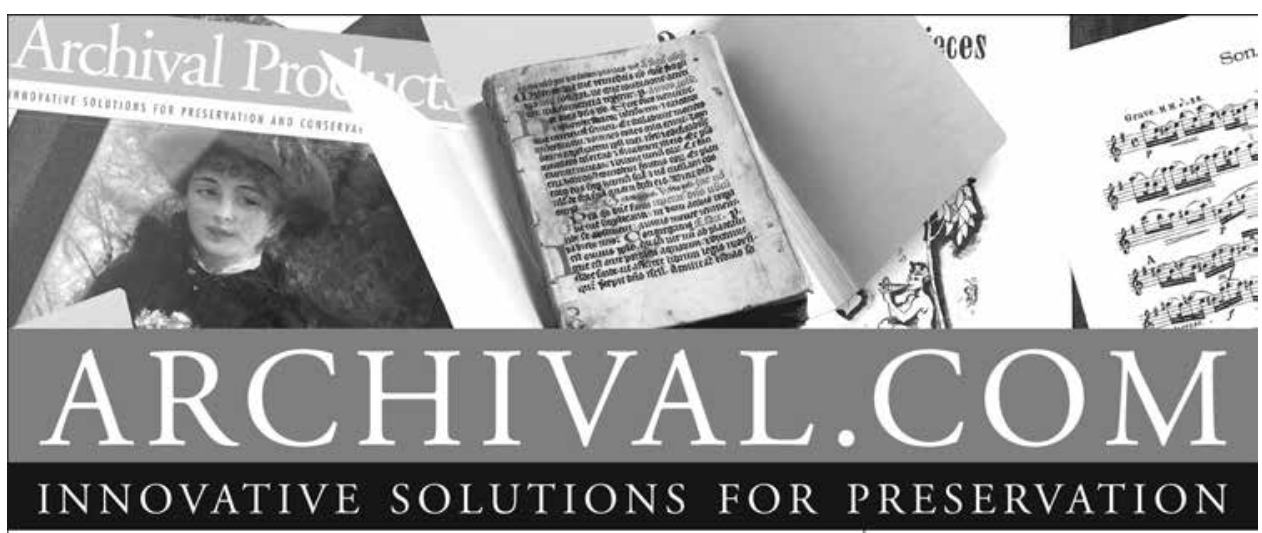

Call for a complete catalog

Pamphlet Binders

Music Binders

Archival Folders

Manuscript Folders

Hinge Board Covers

Academy Folders

Newspaper/Map Folders

Bound Four Flap

Enclosures

Archival Binders
Polypropylene Sheet \& Photo Protectors Archival Boards Adhesives Bookkeeper Century Boxes

Conservation Cloths Non-Glare Polyproplyene Book Covers CoLibri Book Cover System

\section{ARCHIVAL PRODUCTS}

P.O. Box 1413

Des Moines, Iowa 50306-1413

Phone: 800.526.5640

Fax: 888.220.2397

E-mail: custserv@archival.com

Web: archival.com 